\title{
DETECTION OF RAW COW'S, BUFFALO'S MILK AND UHT MILK ADULTERATION IN ASSIUT GOVERNORATE, EGYPT
}

\author{
YASSER, S., WAFY \\ Fellow, Assiut University Hospitals Egypt
}

Received: 19 June 2019; Accepted: 8 July 2019

\begin{abstract}
A total of 90 random samples of raw cow's, buffalo's milk and UHT milk (30 samples each), from different street vendors, dairy shops and supermarkets in Assiut city, Egypt during the period from April 2018 to march 2019 were collected in a clean, dry and sterile containers, and transferred to the laboratory with a minimum of delay, whereas they directly examined or held in the refrigerator until time of examination. Each milk sample was mixed thoroughly before being divided into 3 sub-samples. The first was used for detection of heat treatment, the second was used for compositional quality evaluation and the third was used for detection of preservatives. The results show that all samples were in raw state and the most prominent types of adulteration were addition of water in different percentages, partial skimming or both and adding salicylic acid and Hydrogen peroxide as preservatives to the examined samples of raw cow's and buffalo's milk. UHT milk appear as the most save milk for use due to its free from any adulteration and preservatives. The methods of adulteration and healthy importance of it were discussed.
\end{abstract}

Kay word: Adulteration, milk, raw, cow's, buffalo's, UHT and Assiut.

\section{INTRODUCTION}

Adulteration of milk was widespread between, milk producers, dairy shops and street vendors for many proposes. The most commen propose of milk adulteration were to increase its volume by addition of water. The second propose of adulteration were skimming of fat which use in manfacture of cream and ghee. the third propose of adulteration were to increase the shelf life of milk by some chemicals like hydrogen peroxide, salicylic acid and even the most lethal chemical formalin are being used (Tariq, 2001) that is a perishable commodity and is likely to be spoiled during summer season when weather becomes very hot. The adulteration of milk by addition of water deteriorates the quality of milk which act as a source of microorganism and chemicals which may be contaminate that water and may cause human health hazards, like gastroenteritis, nausea, vomiting, diarrhea, kidney damage and failure, acute failure of circulatory system, asthma, urticaria, metabolic acidosis, and convulsions in sensitive persons (Awan et al., 2014) and decreases the milk solids not fat contents specially protein. On the other hand skimming or partial skimming of milk inhibit fat and fat-soluble vitamins as A, D, E and K

Corresponding author: Dr. YASSER, S., WAFY

E-mail address: Yasserwafy2014@yahoo.com

Present address: Fellow, Assiut University Hospitals Egypt which are very important for biological processes and normal growth of the body (Santos et al., 2013). Preservatives as formalin, salicylic acid, Hydrogen peroxide, boric acid has adverse effects on antioxidants balance in the human body leading to disturbance in the natural immunity and carcinogenic effect (Clare et al., 2003).

All peoples considered milk as a complete diet for all human been at all stages of life because it contains the essential nutrients as lactose, fat, protein, mineral and vitamins in balanced ratio rather than other foods (Khalid, 2006) so that great deal of effort had been done to produce milk of good keeping quality free from adulteration or preservatives which are save for consumers. So, this study was conducted to determine the various adulterants in raw cow, buffalo and UHT milk by addition of water, skimming of fat or both and adding preservatives as formalin, salicylic acid, Hydrogen peroxide, boric acid and borax.

\section{MATERIALS AND METHODS}

\section{Collection of samples:}

A total of 90 random samples of raw cow's milk, raw buffalo's milk and UHT milk (30 samples each), from different street vendors, dairy farms and supermarkets of Assiut city, Egypt during the period from April 2018 to march 2019 were collected in a clean, dry and sterile containers, and transferred to the laboratory with a minimum of delay, whereas they directly 
examined or held in the refrigerator until time of examination.

\section{Milk Samples:}

Each milk sample $(250 \mathrm{ml})$ was mixed thoroughly before being divided into 3 sub-samples. The first was used for detection of heat treatment, the second was used for compositional quality evaluation and the third was used for detection of preservatives (Standard, 1997).

\section{Methods of examination:}

1- Detection of heat treatment: by using Storch's test (Lampert, 1975).

2- Compositional quality evaluation of examined milk samples. a. Determination of specific gravity (Ling, 1963): by lactometer produced from Hauptner, Solingen, germany

b. Determination of fat \%: By Gerber method (FAO, 1977)

c. Determination of milk solids not fat \% (Harding, 1995).

d. Determination of added water \% (Ling, 1963).

3- Specific chemical tests for detection of preservatives.

a. Detection of formalin (Panda and Bindla, 1998).

b. Detection of salicylic acid (Ling, 1963).

c. Detection of Hydrogen peroxide (Pien et al., 1953)

d. Detection of boric and borax (ling, 1963).

\section{RESULTS}

Table 1: The results of heat treatment.

\begin{tabular}{cccc}
\hline Milk samples & No. of examined samples & $\begin{array}{c}\text { No. of heat treatment } \\
\text { samples }\end{array}$ & $\begin{array}{c}\text { \% of heat treatment } \\
\text { samples }\end{array}$ \\
\hline Raw cow milk & 30 & zero & zero \\
\hline Raw buffalo's milk & 30 & zero & zero \\
\hline
\end{tabular}

Table 2: Statical analytic results of specific gravity of raw cow's milk, raw buffalo's milk and UHT milk

\begin{tabular}{ccccc}
\hline Milk samples & No. of examined samples & Min. & Max. & Mean+SE \\
\hline Raw cow's milk & 30 & 1.022 & 1.032 & $1.029 \pm 0.0006$ \\
\hline Raw buffalo's milk & 30 & 1.024 & 1.035 & $1.030 \pm 0.0008$ \\
\hline UHT milk & 30 & 1.029 & 1.033 & $1.031 \pm 0.0080$
\end{tabular}

- Cow milk $1.028-1.034$, average 1.032

- buffalo's milk1.034-1.036 average 1.034

Table 3: Frequency distribution of the examined raw cow's milk, raw buffalo's milk and UHT milk based on specific gravity.

\begin{tabular}{ccccccc}
\hline & \multicolumn{2}{c}{ Raw cow milk } & Raw buffalo's milk & \multicolumn{2}{c}{ UHT milk } \\
\hline Rang & No. & $\%$ & No. & $\%$ & No. & $\%$ \\
\hline $1.022-$ & 8 & 26.67 & zero & zero & zero & zero \\
\hline $1.024-$ & 4 & 13.33 & 4 & 13.33 & zero & zero \\
\hline $1.026-$ & 7 & 23.33 & 2 & 10 & zero & zero \\
\hline $1.028-$ & 5 & 16.67 & 6 & 20 & 4 & 13.34 \\
\hline $1.030-$ & 3 & 10 & 8 & 26.67 & 14 & 46.67 \\
\hline $1.032-$ & 3 & 10 & 4 & 13.33 & 12 & 40 \\
\hline $1.034-$ & zero & zero & 6 & 20 & zero & zero \\
\hline $1.036-$ & zero & zero & zero & zero & zero & zero \\
\hline Total & 30 & 100 & 30 & 100 & 30 & 100 \\
\hline
\end{tabular}


Table 4: Statical analytic results of fat \% of raw cow's milk, raw buffalo's milk and UHT milk.

\begin{tabular}{ccccc}
\hline Milk samples & No. of examined samples & Min. & Max. & Mean+SE \\
\hline Raw cow milk & 30 & 2.6 & 2.9 & $2.66 \pm 0.0004$ \\
\hline Raw buffalo's milk & 30 & 3.7 & 4.9 & $4.22 \pm 0.0002$ \\
\hline UHT milk & 30 & 3.3 & 3.9 & $3.58 \pm 0.0006$ \\
\hline
\end{tabular}

Table 5: Statical analytic results of solids not fat percentage of raw cow's milk, raw buffalo's milk and UHT milk.

\begin{tabular}{ccccc}
\hline Milk samples & No. of examined samples & Min. & Max. & Mean+SE \\
\hline Raw cow milk & 30 & 4.6 & 8.2 & $6.98 \pm 0.0004$ \\
\hline Raw buffalo's milk & 30 & 6.2 & 7.1 & $6.72 \pm 0.0002$ \\
\hline UHT milk & 30 & 6.6 & 8.8 & $8.60 \pm 0.0006$ \\
\hline
\end{tabular}

E. S. 8.75 Egyptian standard (not less than 8.25\%) (Egyptian Standards, 2005).

Table 6: Added water percentage of the examined raw cow's milk, raw buffalo's milk and UHT milk samples.

\begin{tabular}{ccccc}
\hline Milk samples & No. of examined samples & No. of +ve samples & Min. & Max. \\
\hline Raw cow milk & 30 & 19 & 28.1 & 45.8 \\
\hline Raw buffalo's milk & 30 & 20 & 32.8 & 52.9 \\
\hline UHT cow milk & 30 & 2 & 1.22 & 3.75 \\
\hline
\end{tabular}

Table 7: Detection of some preservatives in the examined raw cow's milk, raw buffalo's milk and UHT milk.

\begin{tabular}{|c|c|c|c|c|c|c|c|}
\hline \multirow[b]{2}{*}{ Test } & \multirow[b]{2}{*}{$\begin{array}{c}\text { No. of examined } \\
\text { samples }\end{array}$} & \multicolumn{2}{|c|}{ raw cow's milk } & \multicolumn{2}{|c|}{ Raw buffalo's milk } & \multicolumn{2}{|c|}{ UHT milk } \\
\hline & & $+\mathrm{ve}$ & $\%$ & $+\mathrm{ve}$ & $\%$ & $+\mathrm{ve}$ & $\%$ \\
\hline Formalin & 30 & zero & Zero & zero & Zero & zero & zero \\
\hline salicylic acid & 30 & 8 & 26.67 & 11 & 36.67 & zero & zero \\
\hline Hydrogen peroxide & 30 & 5 & 16.67 & 6 & 20 & zero & zero \\
\hline boric and borax & 30 & zero & zero & zero & zero & zero & zero \\
\hline Total & 30 & 13 & 43.33 & 17 & 56.67 & zero & zero \\
\hline
\end{tabular}

\section{DISCUSSIONS}

The results in table 1 show that all examined raw cow's and buffalo's milk samples were in raw state not exposed to heat treatment Similar results obtained by, El-Bessary (2006) and Shinawy et al. (2018) for cow milk, and Debnath et al. (2014) and Shinawy et al. (2018) for UHT milk. While positive results obtained by El-Loly et al. (2013) for raw cow's milk and shaker et al. (2015) buffalo's milk.

heat treatment of the milk considered one of the most common type of adulteration (Draaiyer et al., 2009) some producers heat milk as a kind of adulteration to remove fat or any other propose but heat treatment of the milk to produce UHT milk kill microorganisms in the milk and protect consumers from being infected with diseases.

data recorded in Table $2 \& 3$ show that specific gravity of raw cow's milk, raw buffalo's milk and UHT milk ranged from $1.022,1.024$ and 1.029 to $1.032,1.035$ and 1.033 with a mean value of $1.029 \pm 0.0006$, $1.030 \pm 0.0008$ and $1.031 \pm 0.0080$ respectively. The highest frequency distribution were $8(26.67 \%)$ in cow's milk, raw buffalo's milk lied between 1.022$>1.024$ and $1.3 \mathrm{o}->1.32$. and there are $19(63.33 \%)$ from 30 examined samples in cow's milk and 20 (66.66\%) from 30examined samples in buffalo's milk had specific gravity lower than the Egyptian standard (not less than 1.028-1.034, average 1.032 in cow's milk and 1.034-1.036 average 1.034 in buffalo's milk 
(Egyptian Standards, 2013). these results indicated that the examined raw cow's milk, raw buffalo's milk were adulterated by addition of water in the other hand there are $11(36.66 \%)$ from 30 examined samples in cow's milk and $10(33.33 \%)$ from 30examined samples in buffalo's milk and $30(100 \%)$ in UHT milk had specific gravity agree with the Egyptian standards which indicate that these examined raw cow's milk, raw buffalo's milk were not adulterated by addition of water or may be adulterated by both skimming and addition of water.

The results in table (4) show that fat $\%$ of raw cow's milk, raw buffalo's milk and UHT milk ranged from 2.6, 3.7 and 3.3 to $2.9,4.9$ and 3.9 with a mean value of $2.66 \pm 0.0004,4.22 \pm 0.0002$ and $3.58 \pm 0.0006$ similar results were obtained by Sobeih (2000) and Fahmid et al. (2016) in raw cow's and UHT milk and those recorded by Kamel (2000) and shaker et al. (2015) buffalo's milk. This results indicated that the examined raw cow's milk, raw buffalo's milk were adulterated by partial skimming or addition of water while in UHT milk indicated that the examined UHT cow milk not adulterated by this methods (Shinawy et al., 2018).

These results do not agree the Egyptian standard (not less than 3.5 in cow milk and $5.5 \%$ in buffalo's milk (Egyptian Standards, 2013) in case of raw cow's milk, raw buffalo's milk but agree the Egyptian standard in case of UHT milk .

Data recorded in Table (5) show that the solids not fat percentage for the examined the examined raw cow's milk, raw buffalo's milk and UHT milk were ranged from 4.6,6.2 and 6.6 to $8.2,7.1$ and 8.8 with a mean value of $6.98 \pm 0.0004,6.72 \pm 0.0002$ and $8.60 \pm 0.0006$ respectively Nearly similar results in raw cow's milk were reported by Fahmid et al. (2016) and Uddin et al. (2016), Shinawy et al. (2018) while Oyama et al. (1992), Chow and $\mathrm{Hu}$ (1997) and AbdelHameid (2002) in raw buffalo's milk. In UHT milk similar results obtained by Sobeih (2000) Bendale et al. (2015) and Shinawy et al. (2018).

These results do not agree the Egyptian standard (not less than 8.25\%) (Egyptian Standards, 2013) in case of raw cow's milk, raw buffalo's milk but agree the Egyptian standard in case of UHT milk.

The lower SNF content could be attributed mainly to adulteration by addition of water (Harding, 1995) as it decreases only by addition of water and not affected by partial skimming.

Data recorded in Table (6) show that 19 (63.33\%), 20 $(66.66 \%)$ and $2(6.67 \%)$ from examined samples in raw cow's milk, buffalo's milk and UHT milk were adulterated by addition of water of different percentages ranged between $28.1 \%, 32.8 \%$ and $1.22 \%$ to $45.8 \%, 52.9 \%$ and $3.75 \%$ respectively.
The data summarized in Table 7 show that $8(26.67 \%)$ samples of examin raw cow's milk adulterated by adding salicylic acid and 5 (16.67\%) adulterated by adding Hydrogen peroxide as preservatives while $11(36.67 \%)$ by adding salicylic acid and 6(20\%) adulterated by adding Hydrogen peroxide as preservatives in raw buffalo's milk. Similar results obtained by Abdel -Hameid (2002), Barham et al. (2014 b) Shaker et al. (2015) and Debnath et al. (2015) which has adverse effects on antioxidants balance in the human body leading to disturbance in the natural immunity and carcinogenic effect (Clare $e t$ al., 2003). But UHT cow milk samples were free from any preservatives.

\section{CONCLUSION}

Addition of water, partial skimming or both and adding of preservatives considered one of the important methods for adultration of raw milk. Milk producers added water to whole milk to increase the volume of milk during summer season, to successfully deal with the demand (Afzal et al., 2011). Which act as a source of microorganism and chemicals which may be contaminate that water and decreases the milk solids not fat contents specially proteins which is very important for normal growth (Moore et al., 2012 and Santos et al., 2013). Adulteration of milk is a complex problem which is not only affect the human health and high economic costs, (Saad et al., 2005) but also inhibiting the utilization of useful constituents of milk which are very important for normal body growth. So, raw milk in markets must be screened randomly and periodically for adulteration. Skimming or partial skimming of milk inhibit fat and fat-soluble vitamins as $\mathrm{A}, \mathrm{D}, \mathrm{E}$ and $\mathrm{K}$ which are very important for biological processes and normal growth of the body (Kartheek et al., 2011). This study mention the presence of added water in varying degree in the examined raw cow's milk, raw buffalo's milk samples which confirmed adulteration of milk by addition of water. Salsylic acid and hydrogen peroxide has adverse effects on antioxidants balance in the human body leading to disturbance in the natural immunity and carcinogenic effect (Clare et al., 2003). So milk must come from dairy farms apply strict hygienic measures and HACCP system and People must use UHT milk instead of raw milk raw milk in markets must be screened randomly and periodically for adulteration.

\section{REFERENCES}

Abdel-Hameid, K.G. (2002): Studies on the sanitary condition of raw milk in Qena Governorate. M.V.Sc. Thesis, Fac. Vet. Med., Assiut Univ.,

Awan, A.; Nasser, M.; Iqbal, A.; Ali, M.; Iqbal, R. and Iqbal, F. (2014): A study on chemical composition and detection of chemical adulteration in tetra pack milk samples 
commercially available in Multan Pakistan Journal of Pharmaceutical Sciences. 27(1): 183-186.

Bendale, V.T.; Patil, C.L.; Chavan, R.P. and Shinde, D.N. (2015): Analysis of milk quality \& adulteration in milk samples collected from Thane. International Journal of Pharma and Bio Sciences. 6(4): 729-733.

Barham, G.S.; Khaskheli, M.; Soomro, A.H. and Nizamani, Z.A. (2014b): Detection and extent of extraneous water and adulteration in milk consumed at Hyderabad, Pakistan. Journal of Food and Nutrition Sciences. 2(2): 47-52.

Chow, C. and Hu, T. (1997): Effects of seasonal alteration on somatic cell count and milk quality in cow raw milk. J. Chinese Society of Animal Sc., 26 (1): 87-97.

Clare, D.A.; Catignani, G.L. and Swaisgood, H.E. (2003): Biodefense properties of milk: the role of antimicrobial proteins and peptides.Current pharmaceutical design. 9(16): 1239-1255.

Debnath, G.K.; Kober, A.K.M.H.; Chanda, T.; Chanda, G.C. and Bari, M.S. (2014): A Comparative Study on the Quality of Available Brand and Non Brand Fluid Milk Consumed by the People of Chittagong City of

Draaiyer, J.; Dugdill, B.; Bennett, A. and Mounsey, J. (2009): Milk Testing and Payment Systems Resource Book: a practical guide to assist milk producer groups. FAO, Rome, Italy.

Egyptian Standards (2013): Raw Milk Egyptian for Standardization. No. 154.

El-Bessary, M.M.A. (2006): Sanitary status of milk and some milk products marketed in suburbs of Assiut Governorate. Ph.D. Thesis, Fac. Vet. Med. Assiut, Uni. Egypt.

El-Loly, M.M.; Mansour, A.I.A. and Ahmed, R.O. (2013): Evaluation of Raw Milk for Common Commercial Additives and Heat Treatments. Internet Journal of Food Safety. 15, 7-10.

Fahmid, S.; Sajjad, A.; Khan, M.; Jamil, N. and Ali, J. (2016): Determination of chemical composition of milk marketed in Quetta, Pakistan. Int. J. Adv. Res. Biol. Sci, 3(5): 98-103.

FAO (1977): Manual of Food Quality Control, 14/8, page 8 / I.S 1224 - (Pt I) -Determination of milk fat by Gerber method)

Harding, F. (1995): Milk Quality. 1st Ed. Blackie Academic and Professional; Chapman and Hall, New York, London, Tokyo, Madras.

Kamel, Azza, M. (2000): Studies on raw milk quality in Kafr El- Sheik. M.V.Sc., Thesis, Fac. Vet. Med., Tanta., Univ., Egypt

Kartheek, M.; Smith, A.A.; Muthu, A.K. and Manavalan, R. (2011): Determination of adulterants in food: a review. Journal of Chemical and Pharmaceutical Research. 3(2), 629-636.
Khalid, A. (2006): Milk production in Sudan (conference) Kh Sudan, pp.: 1-3.

Shojaei, Z.A. and Yadollahi, A. (2008): Physicochemical and Microbiological Quality of Raw Pasteurized and UHT Milks in Shops. Asian Journal.

Lampert, L.M. (1975): Modern Dairy Products. 3rd Ed., Chemical Publishing Co., Inc., New York.

Ling, T.R. (1963): Textbook of dairy chemistry. Vol. II, 3rd Ed, P.I. 30, Chapman and Hall, London Scientific Research. 1: 532-538.

Oyama, H.; Arai, Y. and Sasano, M. (1992): Quality of raw milk produced in Hokkaido prefecture during the period from 2nd year of Showa (1987) to 3rd year of Heisei (1991): Jap. J. Dairy \& Food Sc., 41: 3, A107-114.

Panda, D. and Bindla, M.P. (1998): Detection of Adulteration In Ghee With Animal Body Fats And Vegetable Oils Using Opacity Test. J. Dairying Foods and Home Sci, 17: 31-36.

Pien, J.; Desirant, J. and Iafontaine, D. (1953): Detection of hydrogen peroxide in milk. Ann. Falsif, Fraudes, Paris, Dairy Sci. Abst, 46:539/540, 416-426.

Santos, P.M.; Pereira, E.R. and Rodrigyez- Saona, L.E. (2013): Rapid detection and quantification of milk adulteration using infrared micro spectroscopy and chemometrics analysis. Food Chemistry, 138: 19-24

Standard, I. (1997): Milk, cream and evaporated milk-determination of total solid content (Reference method). Bureau of Indian Standards, IS-12333, Manak Bhavan, New Delhi: BIS.

Shinawy, S.A.; EL-kholy, A.M.; Zeinhom, M.M.A. and Gaber, A. (2018): DETECTION OF ADULTERATION IN MILK AND SOME DAIRY PRODUCTS. Assiut Veterinary Medical Journal Assiut Vet. Med. J. Vol. 64 No. 157 1-10.

Shaker, A.M.; Abd-alla, A. and ELaref, M.Y. (2015): DETECTIO OF RAW BUFFALO'S MILK ADULTERATION IN SOHAG GOVERNORATE. Assiut Vet. Med. J. Vol. 61 No. 144.

Sobeih Azza, M.K. (2000): Studies on raw milk quality in Kaft El-Sheikh. M.V.Sc., Thesis, Fac. Vet. Med., Kafr El-Sheikh Branch, Tanta University. Egypt.

Tariq, M.A. (2001): Subject: A close look at dietary patterns. http://www. dawn. com/2001/11/05/ ebr13. Htm. Accessed Feb, 2011.

Uddin, M.S.; Habib, M.R.; Islam, M.A.; Afrin, S. and Rashid, M.H. (2016): Quality of raw milk collected from Mymensingh town in Bangladesh. Bangladesh Journal of Animal Science. 45(2): 73-78. 


\title{
الكثف عن طرق غش اللبن البقرى والجاموسى والمعق فى محافظة أسيوط
}

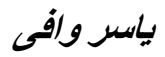 \\ E-mail: Yasserwafy2014@yahoo.com \\ Assiut University web-site: $\underline{w w w . a u n . e d u . e g}$
}

تم جمع ، و عينة عشوائية من ألبان الأبقار الخام والجاموس و وUHT (30 عينة لكل منهم) من مختلف الباعة المتجولين ومحلات

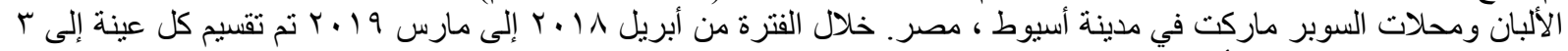

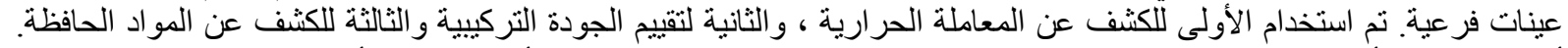

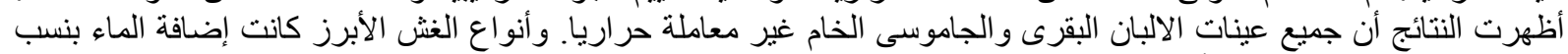

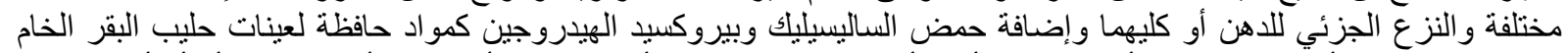

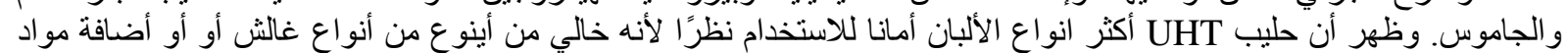

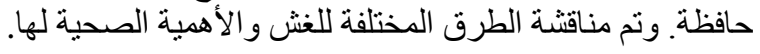

